\title{
STEROIDAL AND PHENOLIC COMPOUNDS FROM Sidastrum paniculatum (L.) FRYXELL AND EVALUATION OF CYTOTOXIC AND ANTI-INFLAMMATORY ACTIVITIES
}

\author{
José Marcílio Sobral Cavalcante, Tiago Bezerra de Sá de Souza Nogueira, Anna Cláudia de Andrade Tomaz, Davi Antas \\ e Silva, Maria de Fátima Agra e Maria de Fátima Vanderlei de Souza* \\ Laboratório de Tecnologia Farmacêutica "Prof. Delby Fernandes de Medeiros", Centro de Ciências da Saúde, Universidade Federal \\ da Paraíba, CP 5009, 58051-970 João Pessoa - PB, Brasil
}

Paulo Roberto Cavalcanti Carvalho, Sílvia Rafaelli Ramos, Silene Carneiro do Nascimento e Teresinha Gonçalves-Silva Departamento de Antibióticos, Universidade Federal de Pernambuco, 50670-901 Recife - PE, Brasil

Recebido em 28/5/09; aceito em 17/11/09; publicado na web em 2/3/10

\begin{abstract}
Sidastrum paniculatum (L.) Fryxell belongs to the family Malvaceae and is popularly known as "malva roxa" or "malvavisco". The phytochemical study of the hexane, $\mathrm{CHCl}_{3}$ and EtOAc phases from the crude ethanol extract of S. paniculatum led to the isolation of six compounds: a mixture of $\beta$-sitosterol and stigmasterol, 4-methoxy-3-hydroxybenzoic acid, 4-methoxy-3-hydroxybenzaldehyde, $\mathrm{N}$-trans-feruloyltyramine and kaempferol-3-O- $\beta$-D-(6"-E-p-coumaroyl) glucoside. The structural identification of the compounds was made on the basis of spectroscopic methods such as IR, ${ }^{1} \mathrm{H}$ and ${ }^{13} \mathrm{C}$ NMR with the aid of including two-dimensional techniques, besides comparison with literature data. The $\beta$-sitosterol and stigmasterol mixture showed a significant anti-inflammatory activity.
\end{abstract}

Keywords: Sidastrum paniculatum; Malvaceae; anti-inflammatory activity.

\section{INTRODUCTION}

Sidastrum paniculatum (L.) Fryxell is a shrub belonging to the family Malvaceae with wide distribution in the neotropics. ${ }^{1}$ In Northeast of Brazil this species is popularly known as "malvaroxa" or "malvavisco". For long time, this species was belonging to the genus Sida, as Sida paniculata L., and was transferred to Sidastrum by Frixell. ${ }^{2}$

Sidastrum Baker $\mathrm{f}$. is one of 70 genera informally included by Bayer and Kubitzki as a member of the tribe Malveae, subfamily Malvoideae (Malvaceae). ${ }^{3}$ The genus comprises about eight species with neotropical distribution, occurring from Mexico to West Indies to Argentina. ${ }^{1,3}$ In Brazil, the northeast region is probably the diversity core of the genus Sidastrum since a great number of species can be found there. ${ }^{1}$

Recent molecular studies of the Sida generic alliance ${ }^{4}$ strongly support the phylogenetic relationships between Sidastrum and the genus Meximalva as well as an Australian group of Sida species, which form a well-supported clade as suggested before by Fryxell ${ }^{1}$ based on morphological characters.

Previous phytochemical studies on species from Malvaceae, specially of the genus Sida have reported the presence of steroids, ${ }^{5-8}$ phenols, ${ }^{6,7,9}$ flavonoids, ${ }^{6-8,10,11}$ triterpenes, ${ }^{5,9}$ essential oils, ${ }^{12}$ alkaloids, ${ }^{13}$ sesquiterpene lactone,,${ }^{14}$ fatty acids, ${ }^{15}$ and phaeophorbide. ${ }^{6}$

Aiming at contributing to the chemotaxonomic study of the family Malvaceae, subfamily Malvoideae, and considering the absence of data in literature concerning the chemical constitution of the genus Sidastrum, the species Sidastrum paniculatum was submitted to a phytochemical study to isolate and identify its chemical constituents, through usual chromatographic and spectroscopic methods, besides comparison with literature data. In addition to that, an evaluation of the cytotoxic and anti-inflammatory activities with some of the isolated compounds will be herein described.

\footnotetext{
*e-mail: mfvanderlei@ltf.ufpb.br
}

\section{EXPERIMENTAL}

\section{General procedures}

NMR spectra (HOMOCOSY, HETCOR, HMQC, HMBC and NOESY) were registered in $\mathrm{CDCl}_{3}, \mathrm{CD}_{3} \mathrm{OD}$ and recorded on a Mercury Varian instrument operating at $200 \mathrm{MHz}$ and $50 \mathrm{MHz}$ for ${ }^{1} \mathrm{H}$ and ${ }^{13} \mathrm{C}$, respectively. The solvent signal was used as internal standard. IR spectra were measured on a Perkin-Elmer, FT-IR-1750 spectrometer in $\mathrm{KBr}$ pellets. Chromatography columns were carried out on silica gel (Merck) and Sephadex LH-20 (Merck). TLC were performed on silica gel $\mathrm{PF}_{254}$ plates and the spots were visualized under UV light (254 and $366 \mathrm{~nm}$ ) and by exposure to the iodine vapor.

\section{Plant material}

The whole plant of $S$. paniculatum was collected in Pedra da Boca, in the municipality of Araruna, State of Paraíba, on February 2004, and a voucher specimen (M. F. Agra et al. 6051) was deposited at the Herbarium Prof. Lauro Pires Xavier (JPB), Universidade Federal da Paraíba.

\section{Extraction and isolation}

The plant material $(10 \mathrm{~kg})$ was subjected to dehydration in an oven in a temperature of $40{ }^{\circ} \mathrm{C}$ for $72 \mathrm{~h}$. After that, it was grounded in a mechanical mill, yielding $5.7 \mathrm{~kg}$ of a powder which was submitted to maceration with ethanol for three consecutive days. This process was repeated until the maximum extraction of the chemical constituents. The obtained ethanol extractive solution was concentrated in a rotatory evaporator, yielding $500 \mathrm{~g}$ of crude ethanol extract (CEE). The latter was suspended in ethanol: $\mathrm{H}_{2} \mathrm{O}(9: 1)$ and successively partitioned with hexane, $\mathrm{CHCl}_{3}$, EtOAc and n-butanol. The hexane phase $(6.0 \mathrm{~g})$ was subjected to column chromatography packed with silica gel and eluted with hexane, $\mathrm{CHCl}_{3}$, EtOAc and methanol. 69 fractions of $20 \mathrm{~mL}$ each were collected, analysed and combined through analytical thin-layer chromatography (TLC). The sub-fraction 37/42 (1.36 g) was rechromatographed on 
silica gel column eluted with hexane, $\mathrm{CHCl}_{3}$ and methanol providing 15 sub-fractions which were analysed and joined through analytical TLC. The sub-fraction 11/15 showed itself as crystals, yielding $0.093 \mathrm{~g}$ of a $\beta$-sitosterol (1) and stigmasterol (2) mixture. The $\mathrm{CHCl}_{3}$ phase provided a precipitate $(5.0 \mathrm{~g})$ and a supernatant $(13.0 \mathrm{~g}) .6 .0 \mathrm{~g}$ of the latter were submitted to chromatography on a column packed with silica gel and eluted with hexane, EtOAc and methanol, giving 200 fractions that were analysed and joined through analytical TLC. Fraction $5 / 15(0.81 \mathrm{~g})$ was also chromatographed on silica gel column using the above chromatographic procedures, yielding 120 sub-fractions.

The sub-fraction 26/57 (0.05 g) showed itself as an amorphous solid, defined as 4-hydroxy-3-methoxybenzoic acid (3). Fraction 26/102 (0.45 g), on the other hand, was chromatographed following the same methodology, providing 96 sub-fractions of which the sub-fraction 43/56 was recrystallized in chloroform and methanol, yielding $0.025 \mathrm{~g}$ of the 4-hydroxy-3-methoxybenzaldehyde (3). $0.15 \mathrm{~g}$ of the precipitate was submitted to preparative TLC, using a mixture of hexane:ethyl acetate (1:1) as eluent, resulting on the isolation and purification of $0.021 \mathrm{~g}$ of $\mathrm{N}$-trans-feruloyltyramine (4). The ethyl acetate phase $(3.0 \mathrm{~g})$ was subjected to chromatography column packed with Sephadex LH-20 and eluted with methanol, providing 23 fractions that were analysed and combined through analytical TLC. The sub-fraction 12/16 (0.087 g) was also chromatographed on Sephadex LH-20, yielding 14 fractions. The sub-fraction 5/8 (0.032 g) was defined as kaempferol-3-O- $\beta$-D-(6"- $E$ - $p$-coumaroyl) glucoside (5).

4 (N-trans-feruloyltyramine) ${ }^{1} \mathrm{H} \mathrm{NMR}\left(\delta, \mathrm{CDCl}_{3}, 200 \mathrm{MHz}\right): 7.37$ ( $d, J=15.8 \mathrm{~Hz}, \mathrm{H}-7), 6.96$ (d, J=8.4 Hz, H-2'/6'), 6.93 ( $\mathrm{brd}, J=8.4$ Hz, H-6), 6.90 (brs, H-2), 6.74 ( $d, J=8.4$ Hz, H-5), 6.68 ( $d, J=8.4 \mathrm{~Hz}$, H-3'/5'), 6.16 ( $d, J=15.8 \mathrm{~Hz}, \mathrm{H}-8), 3.79$ ( $\left.s, \mathrm{OCH}_{3}-3\right), 3.43$ ( $t, J=6.9$ $\left.\mathrm{Hz}, \mathrm{H}-8^{\prime}\right), 2.67$ ( $t, J=6.9 \mathrm{~Hz}, \mathrm{H}-7$ '). ${ }^{13} \mathrm{C}$ NMR (50 MHz): 167.04 (C9), 155.17 (C-4'), 147.69 (C-3), 147.20 (C-4), 155.17 (C-4'), 140.89 (C-7), 129.68 (C-1'), 129.53 (C-2’/6'), 126.82 (C-1), 121.89 (C-6), 117.47 (C-8), 115.17 (C-3'/5'), 114.91 (C-5), 109.70 (C-2), 55.56 $\left(\mathrm{OCH}_{3-} 3\right), 40.89$ (C-8'), 34.41 (C-7').

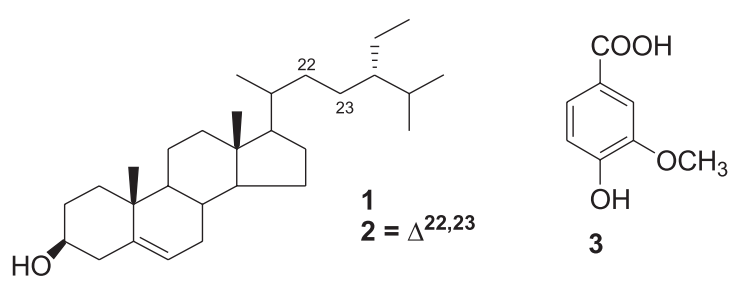<smiles>COc1cc(/C=C/C(=O)NCCc2ccc(O)cc2)ccc1O</smiles><smiles>O=C(/C=C/c1ccc(O)cc1)OCC(OCOc1c(-c2ccc(O)cc2)oc2cc(O)cc(O)c2c1=O)C(O)CO</smiles>

Figure 1. Chemical constituents isolated from Sidastrum paniculatum

\section{Cells}

The cytotoxicity of $\beta$-sitosterol and stigmasterol mixture was tested against NCI-H292 (carcinoma of human lungs), HEp-2 (human larynx epidermoid carcinoma) and KB (mouth carcinoma) cells all obtained from the Bank of Cells, Rio de Janeiro, Brazil. The cells were grown in DMEM - Minimum Essential Medium Eagle modified Dulbecco's- medium supplemented with $10 \%$ fetal bovine serum, 2 $\mathrm{mM}$ glutamine, $100 \mu \mathrm{g} / \mathrm{mL}$ streptomycin, $100 \mathrm{UmL}^{-1}$ penicillin at $37{ }^{\circ} \mathrm{C}$ with a $5 \% \mathrm{CO}_{2}$ atmosphere.

\section{Animals}

Swiss albino female mice weighing 25-30 g, obtained from the Animal House of Departamento de Antibióticos from Universidade Federal de Pernambuco, Brazil, were used. The animals were housed in cages with free access to food and water. All animals were kept under $12 \mathrm{~h}$ light/dark cycle (lights on at 6:00 a.m.). The animals were treated according to the ethical principles of animal experimentation of COBEA (Brazilian College of Animal Experiments), Brazil, and the rules of the National Institute of Health Guide for Care and Use of Laboratory Animals. The Animal Studies Committee of the Universidade Federal de Pernambuco approved the experimental protocols (number 116/07).

\section{Cell proliferation assays}

The tumor cell growth was quantified by the ability of living cells to reduce the yellow dye 3-(4,5-dimethyl-2-thiazolyl)-2,5-diphenyl$2 \mathrm{H}$-tetrazolium bromide (MTT) to a purple formazan product. A cellular suspension $\left(10^{5}\right.$ cells $\left./ \mathrm{mL}\right)$ was prepared and distributed in 96-well $(225 \mu \mathrm{L} /$ well $)$ and incubated during $24 \mathrm{~h}$ at $37{ }^{\circ} \mathrm{C}$. After that, the $\beta$-sitosterol and stigmasterol mixture was added. At the end of incubation ( $72 \mathrm{~h}$ ), the plate was centrifuged and the medium was then replaced by fresh medium $(200 \mu \mathrm{L})$ containing $25 \mu \mathrm{L}$ of MTT. Three hours later, the MTT formazan product was dissolved in 100 $\mu \mathrm{L}$ DMSO, and the absorbance was measured using a multiplate reader. ${ }^{16,17}$ The drugs effects were quantified as the percentage of control absorbance of reduced dye at $595 \mathrm{~nm}$. The tested concentrations were $10.0 ; 5.0 ; 2.5$ and $1.25 \mu \mathrm{g} / \mathrm{mL}$ and the experiments were done in triplicate.

\section{Statistical analysis}

Results are presented as means \pm s.e.m. for groups of six animals for in vivo experiments, and they are representative of two independent experiments. The differences between the experimental groups were compared by analysis of variance (ANOVA) complemented with Student's t-tests. $P<0.05$ was considered as indicative of significance.

\section{Anti-inflammatory activity}

Air pouches were produced on the dorsal cervical region of mice by subcutaneous injection of $2.5 \mathrm{~mL}$ on day 0 , followed by a second injection of $2.5 \mathrm{~mL}$ of sterile air 3 days later. At day 6,1 $\mathrm{mL}$ of a carrageenan solution $1 \%(\mathrm{w} / \mathrm{v})$ was injected into the cavity. The B-sitosterol and stigmasterol mixture $(10,30$ and $90 \mathrm{mg} / \mathrm{kg}$ ) and dexamethasone (3 mg/kg) were administered (p.o.) $1 \mathrm{~h}$ before injection of carrageenan. After killing the animals ( $6 \mathrm{~h}$ after inflammation induction), pouches were washed with $3 \mathrm{~mL}$ of saline solution containing $3 \mathrm{mM}$ EDTA. Samples from the air pouch exudates were collected for determinations of total and differential leukocyte contents. Total leukocyte counts were performed in a Neubauer chamber after diluting the exudates with Turk's solution (1:20) and cytospin preparations of exudates were stained with May-Grunwald Giemsa for the differential leukocyte count, which was performed under an oil immersion objective. ${ }^{16}$ 


\section{RESULTS AND DISCUSSION}

The structural assignments of compounds 1-3 and $\mathbf{5}$ were made based on the spectral analysis and are in good agreement with those reported in the literature. Thus, their structures were identified as the mixture of the steroids $\beta$-sitosterol and stigmasterol (1), ${ }^{18} 4$-hydroxy3-methoxybenzoic acid (2), ${ }^{7,19}$ 4-hydroxy-3-methoxybenzaldehyde $(3)^{20}$ and kaempferol 3-O- $\beta$-D-(6" -E-p-coumaroyl) glucopyranoside (5) (tiliroside)..$^{6,710}$ All compounds are being reported here for the first time in the genus Sidastrum. The compound 5 (tiliroside) was previously isolated from the Malvaceae species Sida galheirensis, ${ }^{6}$ Bakeridesia pickelli, ${ }^{7}$ Herissantia crispa,${ }^{8}$ and Herissantia tiubae ${ }^{10}$ However, the presence of the compound $\mathbf{5}$ (tiliroside) in species of Malvaceae does not represent it as a chemical marker, because it was reported also to be present in other species of angiosperms like Solanum $^{21}$ belonging to the Solanaceae family, as an example.

The IR spectrum of compound $\mathbf{4}$ showed a large absorption band at $3300-3350 \mathrm{~cm}^{-1}$ (N-H bending) and at $1658 \mathrm{~cm}^{-1}(\mathrm{C}=\mathrm{O}$ stretch $)$ suggesting an amide function. The aromatic skeleton was evidenced by the absorptions between 1600 and $1450 \mathrm{~cm}^{-1}$. The ${ }^{1} \mathrm{H}$ NMR spectra showed a pair of doublets at $\delta 6.68$ and $6.96(2 \mathrm{H}, J=8.4 \mathrm{~Hz})$, which suggests an AA'BB'-type system of hydrogens bonded to aromatic carbon. It showed yet a doublet at $\delta 6.74(1 \mathrm{H}, J=8.4 \mathrm{~Hz})$ together with a broad doublet at $\delta 6.93(1 \mathrm{H}, J=8.4 \mathrm{~Hz})$ and a broad singlet at $\delta 6.90(1 \mathrm{H})$, characterizing AMX system.

Those IR and ${ }^{1} \mathrm{H}$ NMR data together with a pair of doublets at $\delta$ $6.16(\mathrm{H}-8, J=15.8 \mathrm{~Hz})$ and $7.37(\mathrm{H}-7, J=15.8 \mathrm{~Hz})$ referring to trans olefinic hydrogens and a pair of triplets at $\delta 2.67$ and 3.43 (H-7' and $\mathrm{H}-\mathrm{8}^{\prime}$ ), suggested the presence of the coumaroyl and tyramine units, respectively. A methoxyl group in one of the aromatic nuclei was inferred by the signal at $\delta 3.79$.

The ${ }^{13} \mathrm{C}$ NMR spectral data strengthened the information provided by the IR and ${ }^{1} \mathrm{H}$ NMR spectra, emphasizing the presence of the amide function due to the signal at $\delta 167.04$ ( $\alpha, \beta$-unsaturated carbonyl) thus reinforcing the coumaroyl unit because of the $\alpha, \beta$-unsaturated carbons (C-8 and C-7) at $\delta 117.47$ and 140.89, respectively, as well as the tyramine unit whose methylene carbons were shown to be at $\delta 34.41$ (C-7') and 40.89 (C-8'). The absorptions at $\delta 115.17$ and 129.53 (2C, C-3'/5' and C-2'/6') corroborated the AA'BB' system, while a methoxyl group was suggested by the signal at $\delta 55.56$. Nonhydrogenated carbons bound to oxygen groups were inferred by the signals at $\delta 147.20,147.60$ and 155.12.

The heteronuclear correlation spectrum HMBC confirmed the suggestion of the $\alpha, \beta$-unsaturated amide strengthening the presence of the coumaroyl and tyramine units since it showed, respectively, two- and three-bond correlations $\left({ }^{2,3} J_{\mathrm{CH}}\right)$ between $\mathrm{H}-7$ ' and $\mathrm{H}-8$ ' with C-1', and ${ }^{2} J_{\mathrm{CH}}$ and ${ }^{3} J_{\mathrm{CH}}$ correlations between H-8 and H-7 with the carbonyl carbon, respectively (Figure 2).

The homonuclear correlation spectrum NOESY revealed the space interactions between the methoxyl hydrogens with $\mathrm{H}-2$, thus determining the meta position for the methoxyl group in the coumaroyl portion of the molecule (Figure 2).

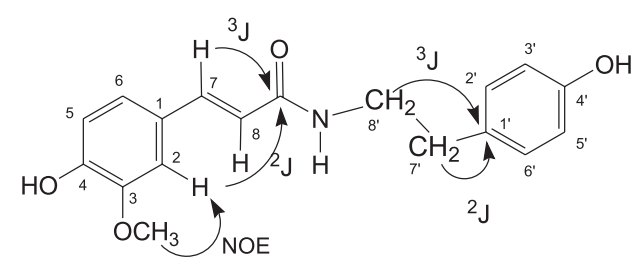

Figure 2. Main correlations observed at the HMBC $\left({ }^{n} \mathrm{~J}\right)$ and NOESY (NOE) spectra of 4
The other assignments of carbons and hydrogens were determined based on all spectral data and in comparison with the literature ones, ${ }^{22}$ which allowed to unambiguously identify substance $\mathbf{4}$ as being $\mathrm{N}$ trans-feruloyltyramine (Figure 3), substance already isolated from other vegetal species ${ }^{23}$ with studies demonstrating its action against weeds and improvement of seed germination, ${ }^{24}$ as well as its activity as a melanin biosynthesis inhibitor, ${ }^{22}$ being described for the first time in the family Malvaceae.

In vitro activity of $\beta$-sitosterol and stigmasterol mixture against three human tumor cell lines was determined. However, the mixture assayed did not show cytotoxicity at the tested concentrations.

According to the protocol of National Cancer Institute (NCIUSA), natural products from plants are considered cytotoxic if $\mathrm{IC}_{50}$ $30 \mu \mathrm{g} / \mathrm{mL}$. The mixture tested exhibited $\mathrm{IC}_{50}$ values greater than 10 $\mu \mathrm{g} \mathrm{mL} \mathrm{m}^{-1}$ for all tumor cell lines tested. The results suggested that the compounds tested showed low cell toxicity, which is desirable in case of anti-inflammatory activity. Literature shows that some compounds isolated from Hisbiscus taiwanensis (Malvaceae) also did not show cytotoxic activity against human cells H.549 (lung carcinoma) and NC5-7 (breast carcinoma) up dose of $20 \mu \mathrm{g} / \mathrm{mL} .^{25}$

The $\beta$-sitosterol and stigmasterol mixture showed a significant anti-inflammatory activity when compared to control group, inhibiting the carrageenan-induced cell migration by at rates of $30,56.8$ and $81.2 \%$ of doses 10,30 and $90 \mathrm{mg} / \mathrm{kg}$, respectively (Figure 3 ). The number of polymorphonuclear leucocytes which migrated to the peritoneal cavity in the control group was $4.53 \pm 0.8$ and in dexamethasone pattern was $0.90 \pm 0.3 \times 10^{6}$ cells per cavity ( $p<0.05$ for all doses).

Anti-inflammatory activity of b-sitosterol and stigmasterol mixture

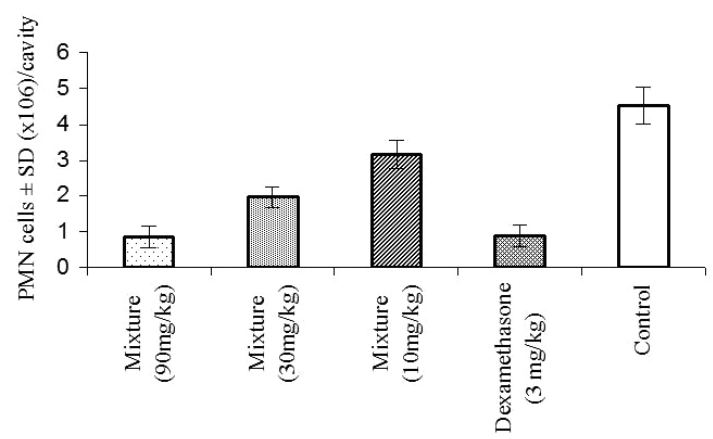

Figure 3. $P M N L=$ polymorphonuclear leucocytes; $P M N L$ count is expressed as total cell number by volume of exudate. Values represent average \pm standard deviation

The anti-inflammatory activity of $\beta$-sitosterol ${ }^{26}$ in the carrageenan paw edema model has been reported. It has been demonstrated that the stigmasterol was active in reducing the edema by $41 \%$ inhibition at doses of $0.5 \mathrm{mg} / \mathrm{ear}^{27}$ Most articles on anti-inflammatory activity describe the most common type of evaluation which are the carrageenan-induced paw edema ${ }^{26}$ and the TPA-induced ear edema. ${ }^{27}$ However, as several authors describe in the literature, the paw edema test is not specific for anti-inflammatory drugs, as anti-cholinergic drugs also reduce the edema. Furthermore, we found only one study that evaluates the activity of MPO; ${ }^{27}$ however, no studies evaluate the cell migration of the mixture $\beta$-sitosterol and stigmasterol, and it is known that cell migration is an important step in the developing of acute inflammation. Besides, we also aimed at verifying whether the mixture of those steroids possess synergistic action, and our data suggest that they do, since anti-inflammatory effects of $\beta$-sitosterol isolated in the model of carrageenan-induced paw edema were not 
observed. ${ }^{28}$ The $\beta$-sitosterol and stigmasterol mixture showed a promising anti-inflammatory activity, when compared to dexamethasone, being greater than that of the isolated products, suggesting synergistic action between $\beta$-sitosterol and stigmasterol. However, this was only one preliminary study with the mixture; further studies are necessary to provide the investigation of its mechanism of action.

\section{SUPPLEMENTARY MATERIAL}

Available in http://quimicanova.sbq.org.br, in format .PDF, with free access.

\section{REFERENCES}

1. Fryxell, P. A.; Brittonia 1997, 49, 204.

2. Fryxell, P. A.; Brittonia 1978, 30, 447.

3. Bayer, C.; Kubitzki, K. In Flowering plants, dicotyledons: Malvales, Capparales, and nonbetalain Caryophyllales; Kubitzki, K.; Bayer, C., eds.; Springer-Verlag: Berlin, 2003, 225.

4. Aguilar, J. F.; Fryxell, P. A.; Jansen, R. K.; Syst. Bot. 2003, 28, 352; Tate, J. A.; Aguilar, J. F.; Wagstaff, S. J.; La Duke, J. C.; Slotta, T. B.; Simpson, B. B.; Am. J. Bot. 2005, 92, 584.

5. Ahmed, Z.; Kazmi, S. N. H.; Walik, A.; J. Nat. Prod. 1990, 53, 1342.

6. Silva, D. A.; Silva, T. M. S.; Lins, A. C. S.; Costa, D. A.; Cavalcante, J. M. S.; Matias, W. N.; Souza, M. F. V.; Quim. Nova 2006, 29, 1250.

7. Costa, D. A.; Silva, D. A.; Cavalcanti, A. C.; Medeiros, M. A. A.; Lima, J. T.; Cavalcante, J. M. S.; Silva, B. A.; Agra, M. F.; Souza, M. F. V.; Quim. Nova 2007, 30, 901.

8. Costa, D. A.; Matias, W. N.; Lima, I. O.; Xavier, A. L.; Costa, V. B. M.; Diniz, M. F. F. M.; Agra, M. F.; Batista, L. M.; Souza, M. F. V.; Silva, D. A.; Quim. Nova 2009, 32, 48.

9. Silva; D. A.; Falcão-Silva, V. S.; Gomes, A. Y. S.; Costa, D. A.; Lemos, V. S.; Agra, M. F.; Braz-Filho, R.; Siqueira-Junior, J. P.; Souza, M. F. V.; Pharmaceut. Biol. 2009, 29, 279.

10. Silva D. A.; Chaves M. C. O.; Costa, D. A.; Moraes, M. R. R.; Nóbrega, F. B. P.; Souza, M. F. V.; Pharmaceut. Biol. 2005, 43, 197.

11. Silva, D. A.; Costa, D. A.; Silva, D. F.; Souza, M. F. V.; Agra, M. F.; Medeiros, I. A.; Barbosa-Filho, J. M.; Braz-Filho, R.; Rev. Bras. Farmacogn. 2005, 15, 23.
12. Ames, J. M.; Macleod, G.; Phytochemistry 1990, 29, 1201.

13. Ghosal, S.; Chauhan, R.; Mehta, R.; Phytochemistry 1975, 14, 830.

14. Sharma, P. V.; Ahmad, Z. A.; Phytochemistry 1989, 28, 3525.

15. Carmody, D. R.; Dejong, W.; Smith, T. R.; Oil \& Soap 1945, October, 263; Vickery, J. R.; J. Am. Oil Chem. Soc. 1980, February, 87; Schimid, K. M.; Patterson, G. W.; Phytochemistry 1988, 27, 2831; Nakatani, M.; Fukunaga, Y.; Hase, T.; Phytochemistry 1986, 25, 449.

16. Klemm, P.; Harris, H. J.; Perretti, M.; Eur. J. Pharmacol. 1995, 281, 69.

17. Alley, M. C.; Scudiero, D. A.; Monks, A.; Hursey, M. L.; Czerwinski, M. J.; Fine, D. L.; Abbott, B. J.; Mayo, J. G.; Shoemaker, R. H.; Boyd, M. R.; Cancer Res. 1998, 48, 589.

18. Kojima, H.; Sato, N.; Hatano, A.; Ogura, H.; Phytochemistry 1990, 29, 2351.

19. Tomaz, A. C. C.; Nogueira, R. B. S. S.; Pinto, D. S.; Agra, M. F.; Souza, M. F. V.; Da-Cunha, E. V. L.; Rev. Bras. Farmacogn. 2008, 18, 47.

20. França, V. C.; Tese de Doutorado, Universidade Federal da Paraíba, Brasil, 2002.

21. Esteves-Souza, A.; Silva, T. M. S.; Alves, C. C. F.; Carvalho, M. G.; Braz-Filho, R.; Echevarria, A.; J. Braz. Chem. Soc. 2002, 13, 838.

22. Efdi, M.; Ohguchi, K.; Akao, Y.; Nozawa, Y.; Koketsu, M.; Ishihara, H.; Biol. Pharm. Bull. 2007, 30, 1972.

23. Chen, C. Y.; Chang, P. R.; Wu, Y. C.; J. Chin. Chem. Soc. 1997, 44, 313; Kim, H. R.; Min, H. Y.; Jeong, Y. H.; Lee, S. K.; Lee, N. S.; Seo, E. K.; Arch. Pharmacal Res. 2005, 28, 1224.

24. Miyaichi, Y.; Nunomura, N.; Kawata, Y.; Kizu, H.; Tomimori, T.; Watanabe, T.; Takano, A.; Malla, K. J.; Chem. Pharmaceut. Bull. 2006, 54, 136; Oliveira, P. E. S.; Conserva, L. M.; Lemos, R. P. L.; Biochem. System. Ecol. 2008, 36, 134.

25. Lajide, D.; Escoubas, P.; Mizutani, J.; Phytochemistry 1995, 40, 1105.

26. Gupta, M. B.; Nath, R.; Srivastava, N.; Shanker, K.; Kishor, K.; Bhargava, K. P.; Planta Med. 1980, 39, 157.

27. García, M. D.; Sáenz, M. T.; Gómez, M. A.; Fernández, M. A.; Phytother. Res. 1999, 13, 78.

28. Villaseñor, I. M.; Angelada, J.; Canlas, A. P.; Echegoyen, D.; Phytother. Res. 2002, 16, 417. 


\section{STEROIDAL AND PHENOLIC COMPOUNDS FROM Sidastrum paniculatum (L.) FRYXELL AND EVALUATION} OF CYTOTOXIC AND ANTI-INFLAMMATORY ACTIVITIES

José Marcílio Sobral Cavalcante, Tiago Bezerra de Sá de Souza Nogueira, Anna Cláudia de Andrade Tomaz, Davi Antas e Silva, Maria de Fátima Agra e Maria de Fátima Vanderlei de Souza*

Laboratório de Tecnologia Farmacêutica "Prof. Delby Fernandes de Medeiros", Centro de Ciências da Saúde, Universidade Federal da Paraíba, CP 5009, 58051-970 João Pessoa - PB, Brasil

Paulo Roberto Cavalcanti Carvalho, Sílvia Rafaelli Ramos, Silene Carneiro do Nascimento e Teresinha Gonçalves-Silva

Departamento de Antibióticos, Universidade Federal de Pernambuco, 50670-901 Recife - PE, Brasil

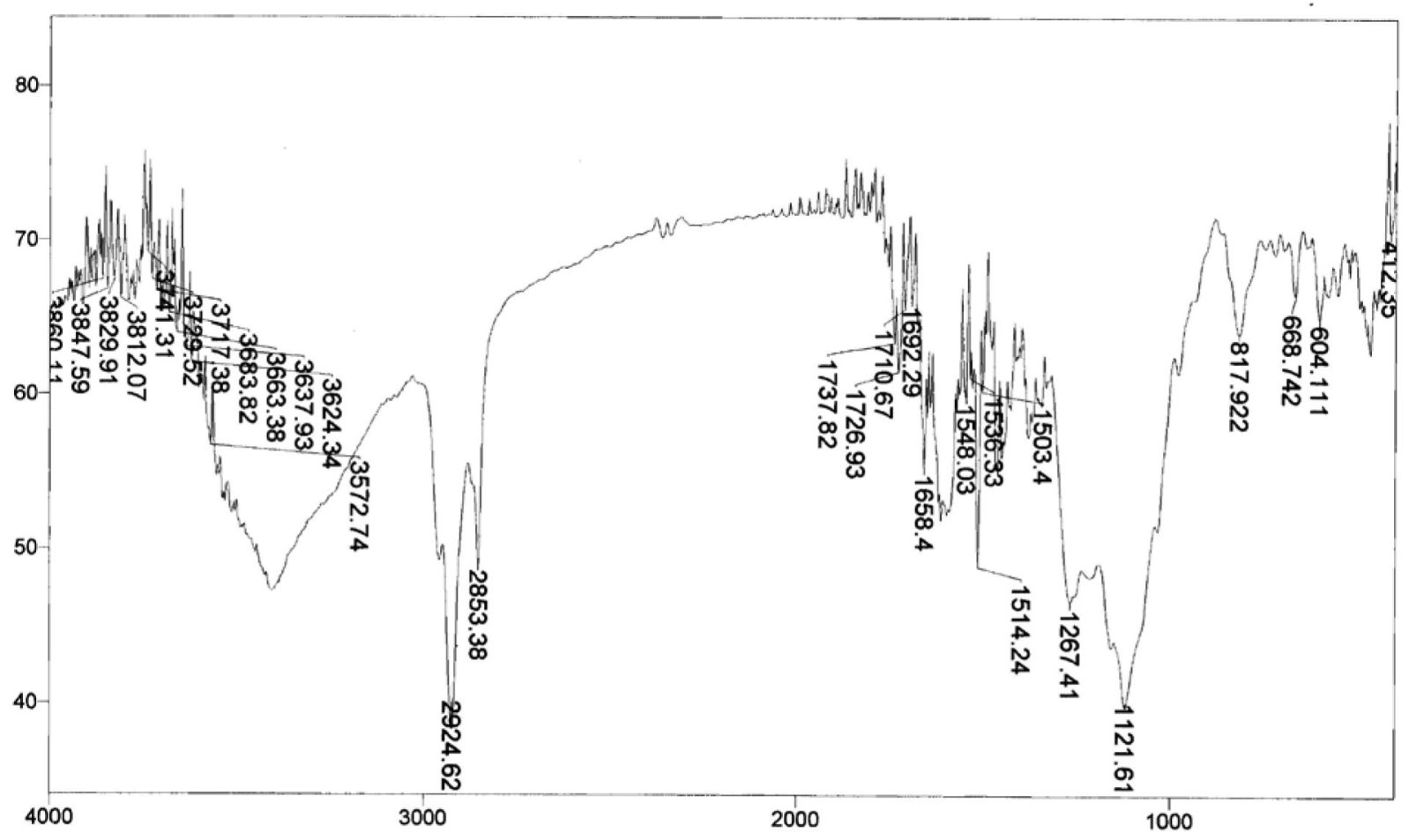

Figure 1S. IR spectrum of $4\left(\mathrm{KBr}, \mathrm{cm}^{-1}\right)$

*e-mail: mfvanderlei@ltf.ufpb.br 
2

Cavalcante et al.

Quit. Nova

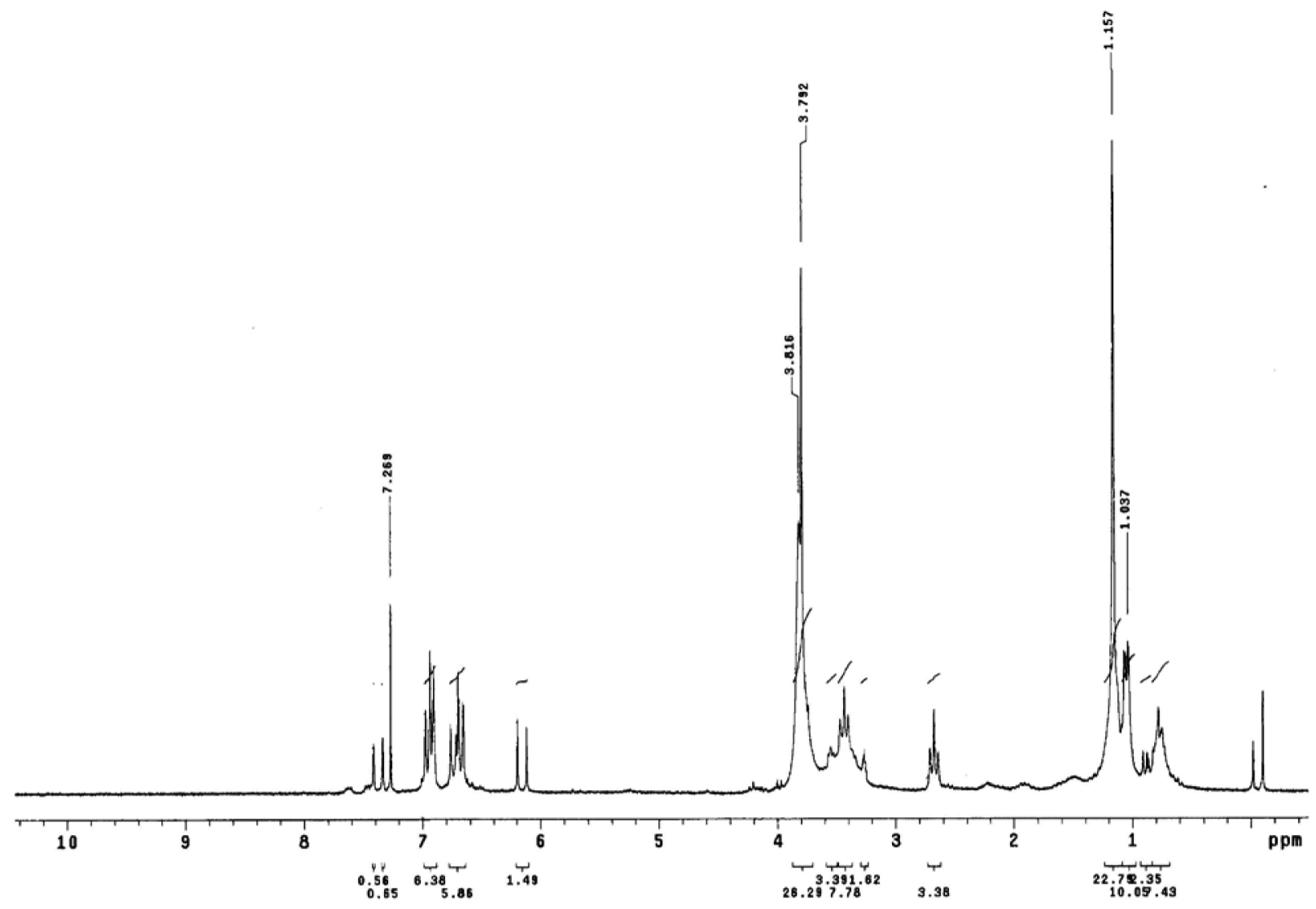

Figure $2 \mathrm{~S} .{ }^{1} \mathrm{H} N \mathrm{NR}$ spectrum of $4\left(\delta, \mathrm{CDCl}_{3}, 200 \mathrm{MHz}\right)$

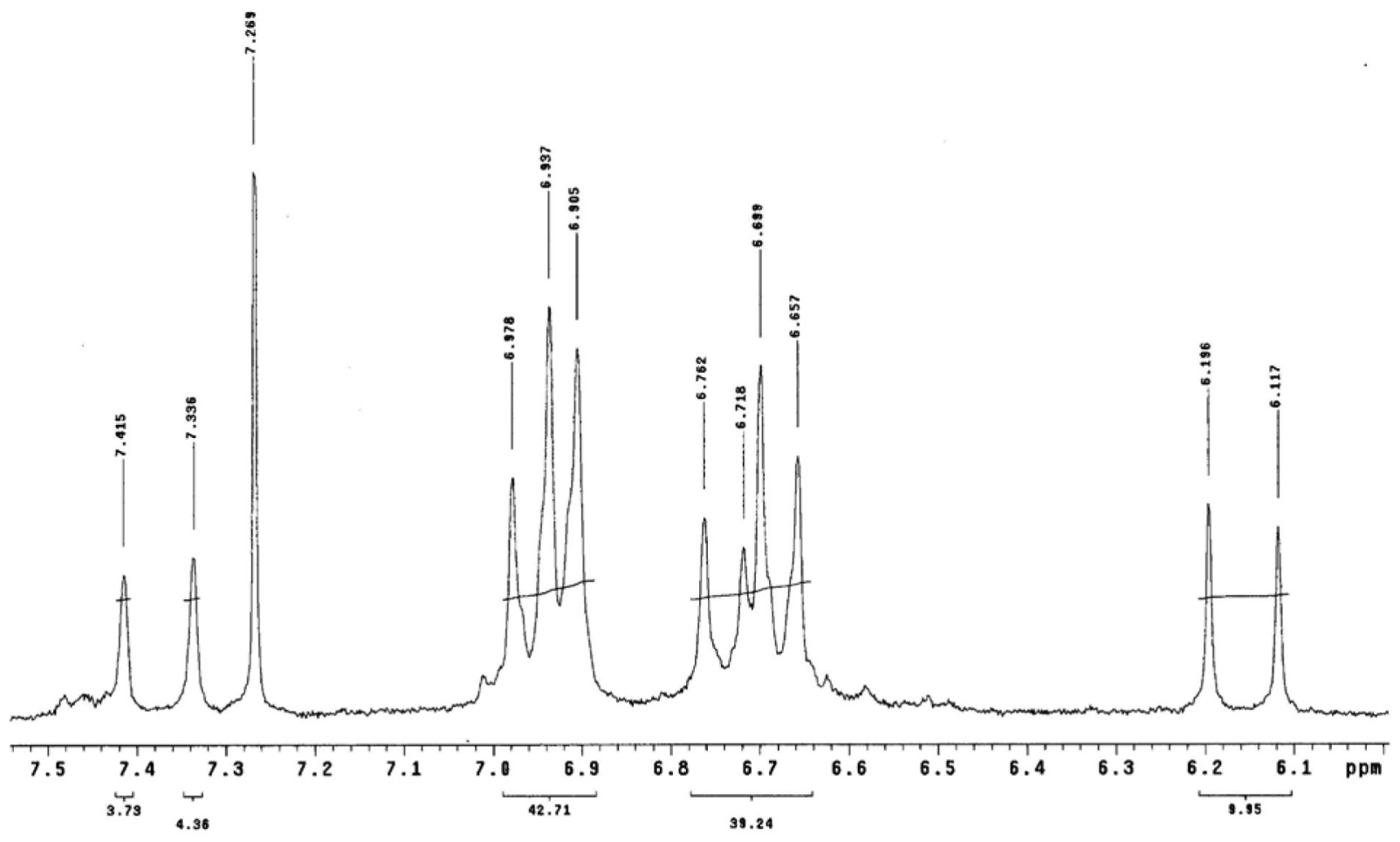

Figure 3S. Expansion of the ${ }^{l} \mathrm{H} N \mathrm{NM}$ spectrum of $4\left(\delta, \mathrm{CDCl}_{3}, 200 \mathrm{MHz}\right)$ 


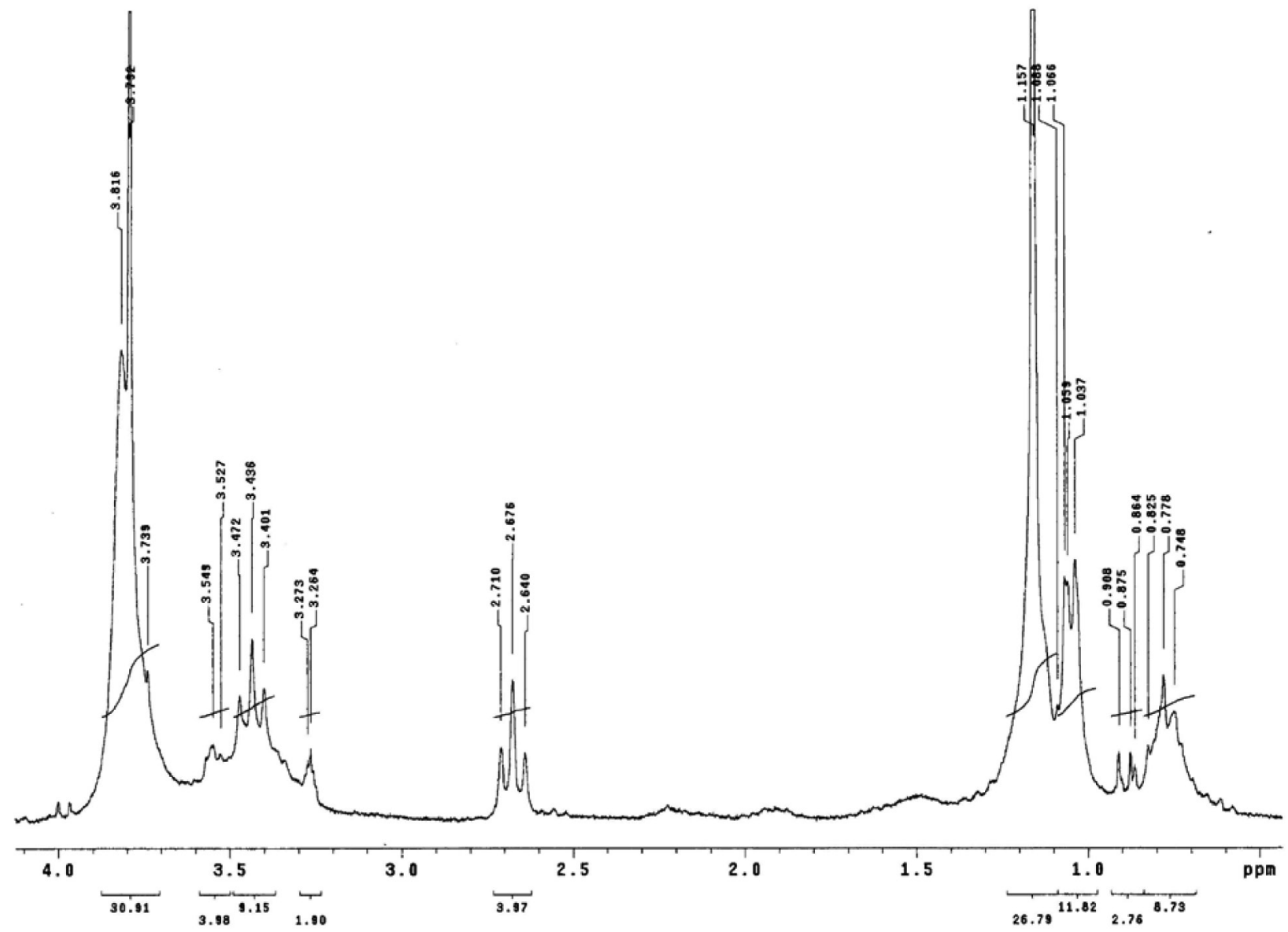

Figure 4S. Expansion of the ${ }^{l} \mathrm{H} N \mathrm{NR}$ spectrum of $4\left(\delta, \mathrm{CDCl}_{3}, 200 \mathrm{MHz}\right)$

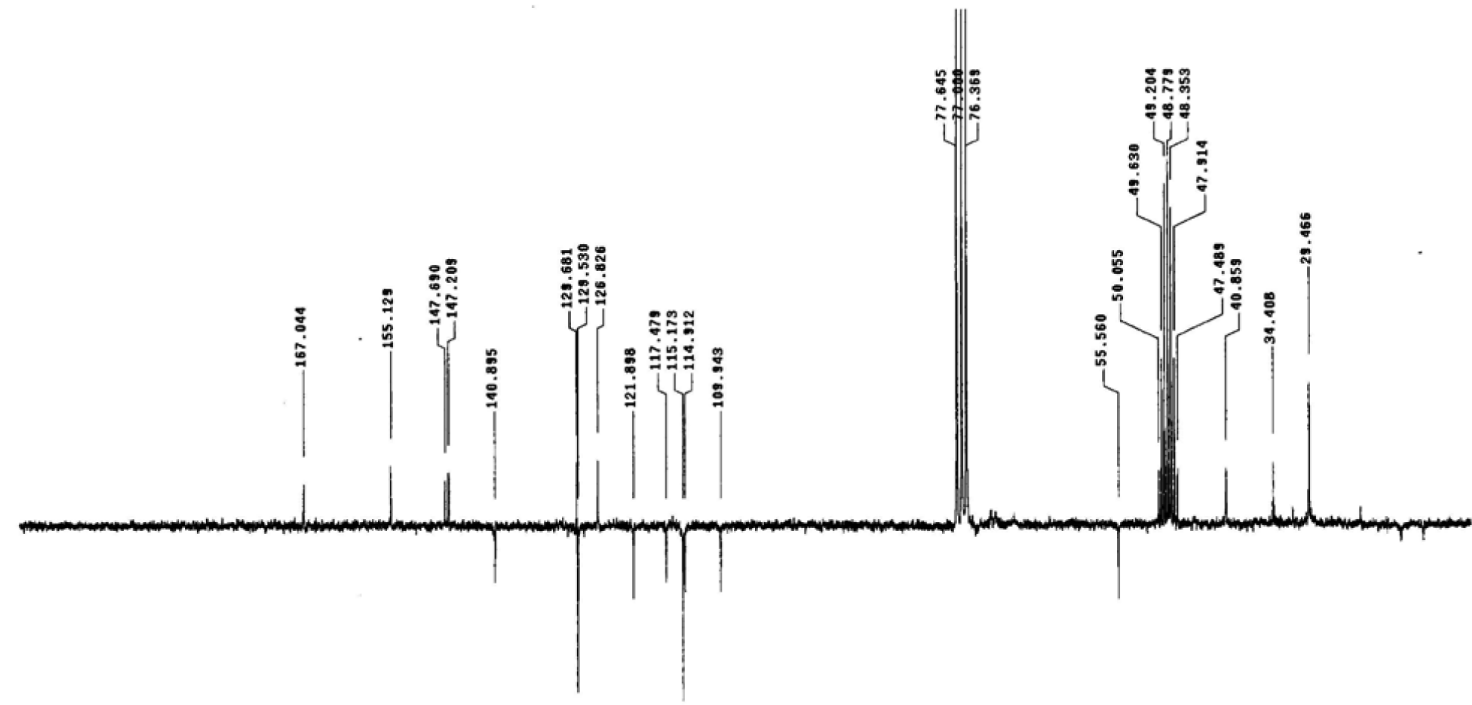

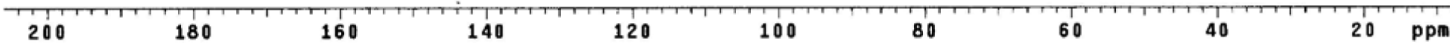




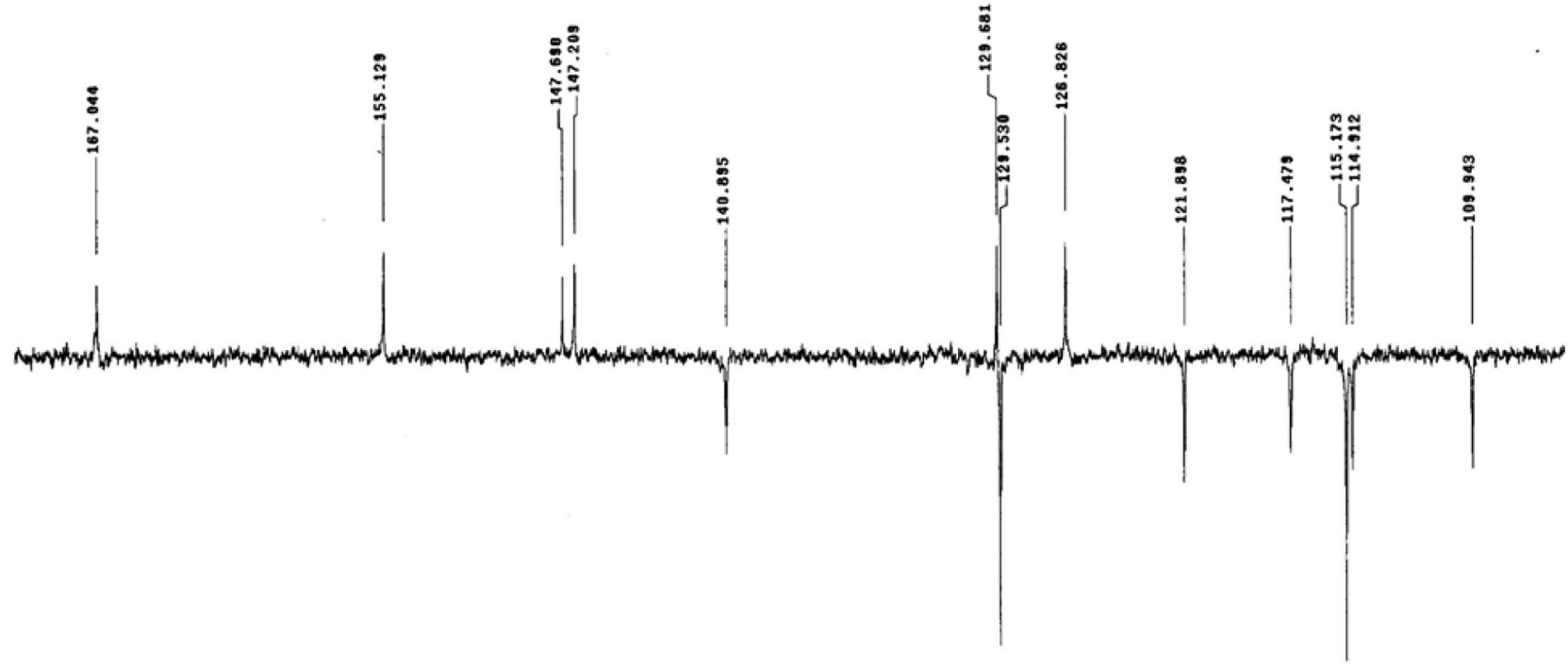

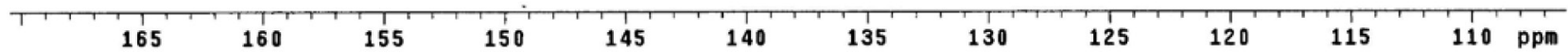

Figure 6S. Expansion of the ${ }^{13} \mathrm{C}-A P T N M R$ spectrum of $4(\delta, C D C l, 50 \mathrm{MHz})$

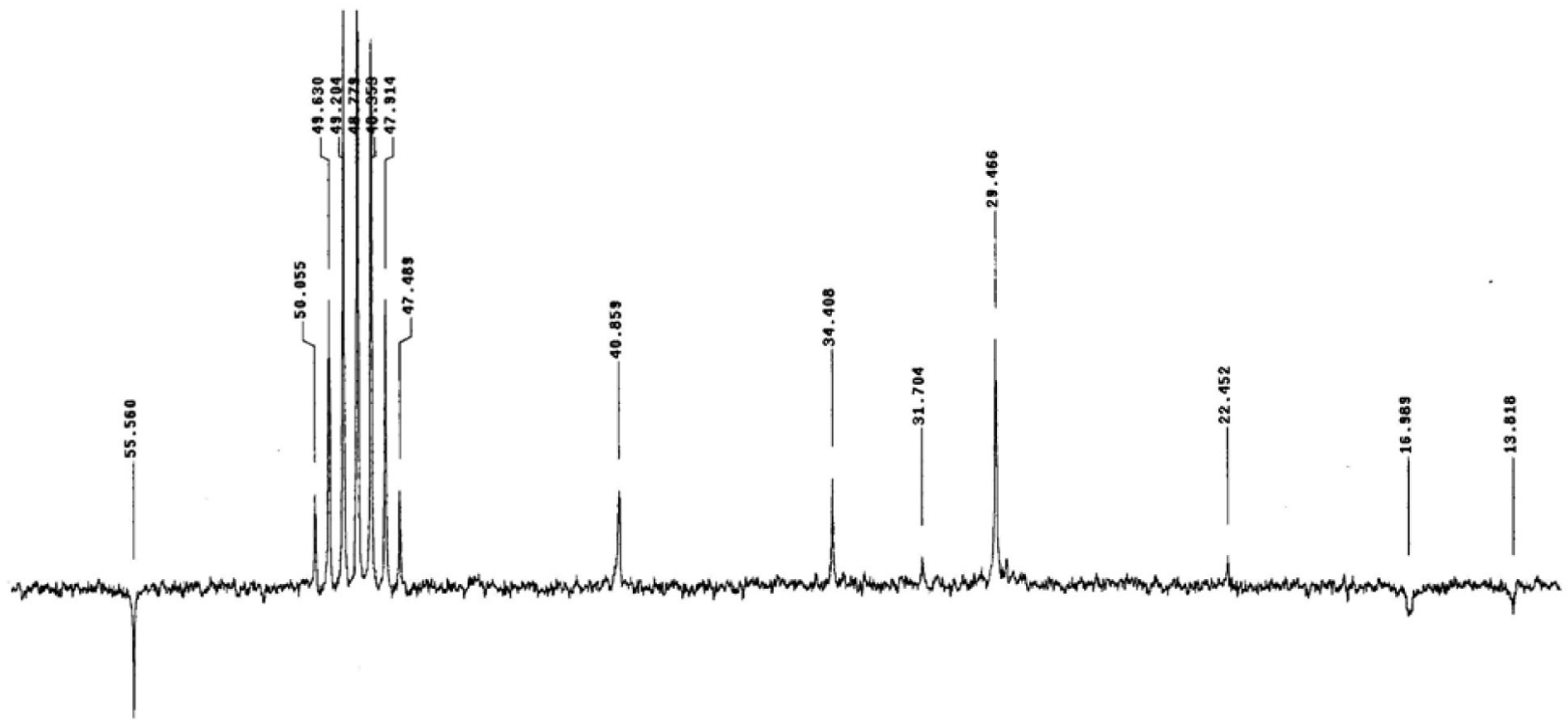

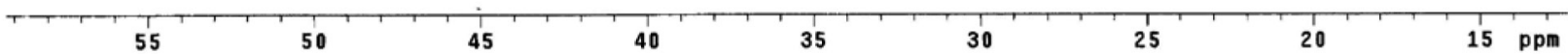




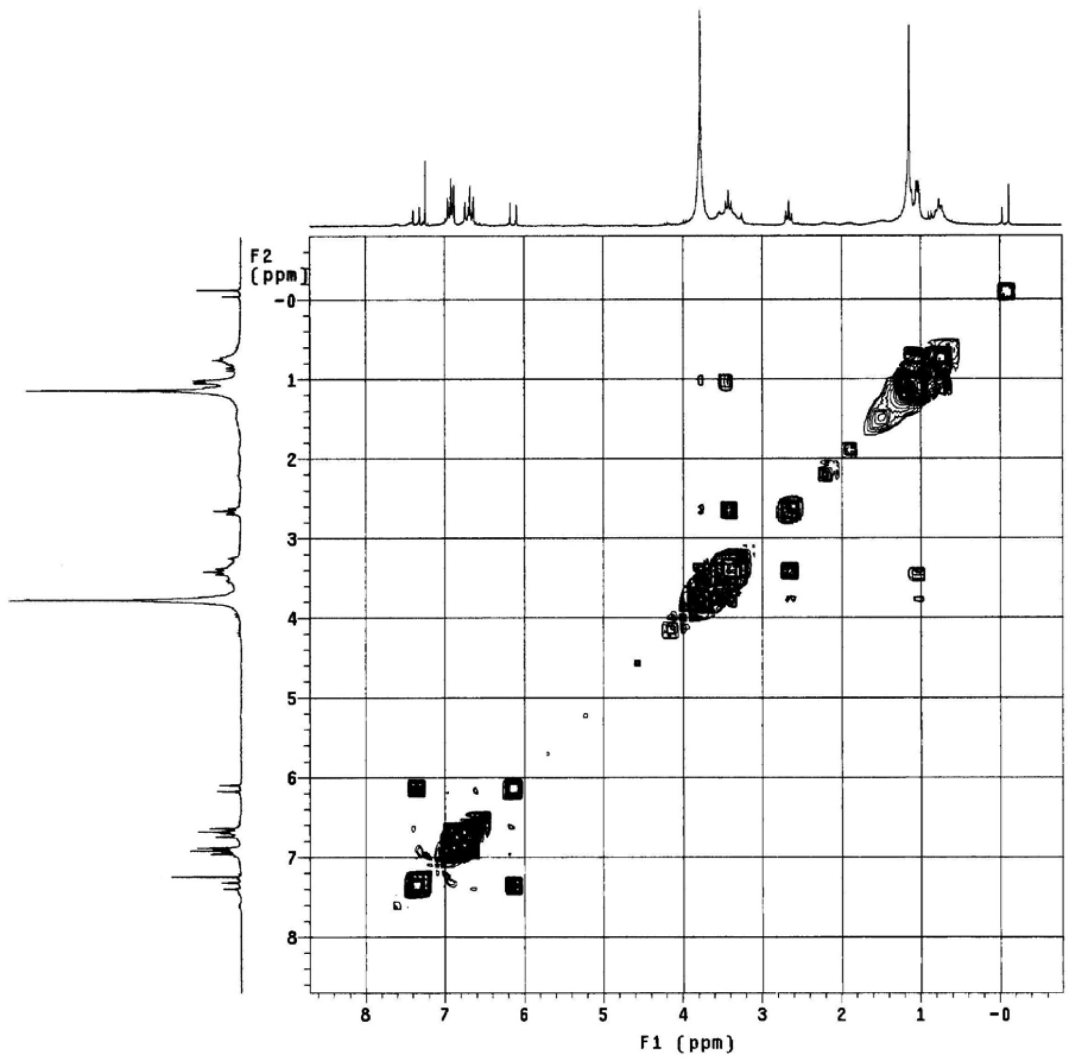

Figure 8S. ${ }^{l} \mathrm{H} x^{l} \mathrm{H}$-COSY NMR spectrum of $4\left(\delta, \mathrm{CDCl}_{3}, 200 \mathrm{MHz}\right)$

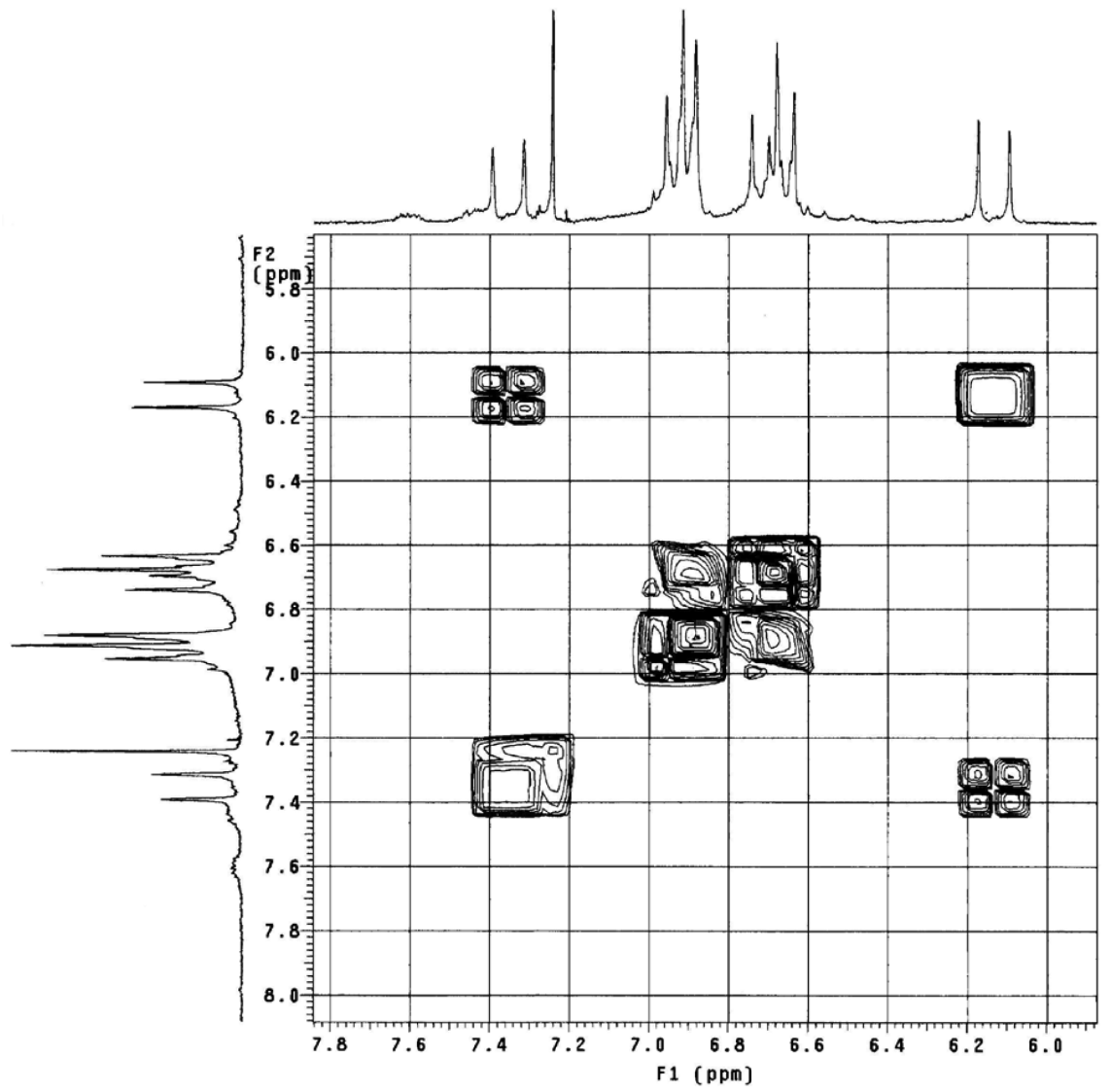

Figure 9S. Expansion of the ${ }^{l} \mathrm{H} x{ }^{l} \mathrm{H}-\mathrm{COSY} \mathrm{NMR}$ spectrum of $4\left(\delta, \mathrm{CDCl}_{3}, 200 \mathrm{MHz}\right)$ 


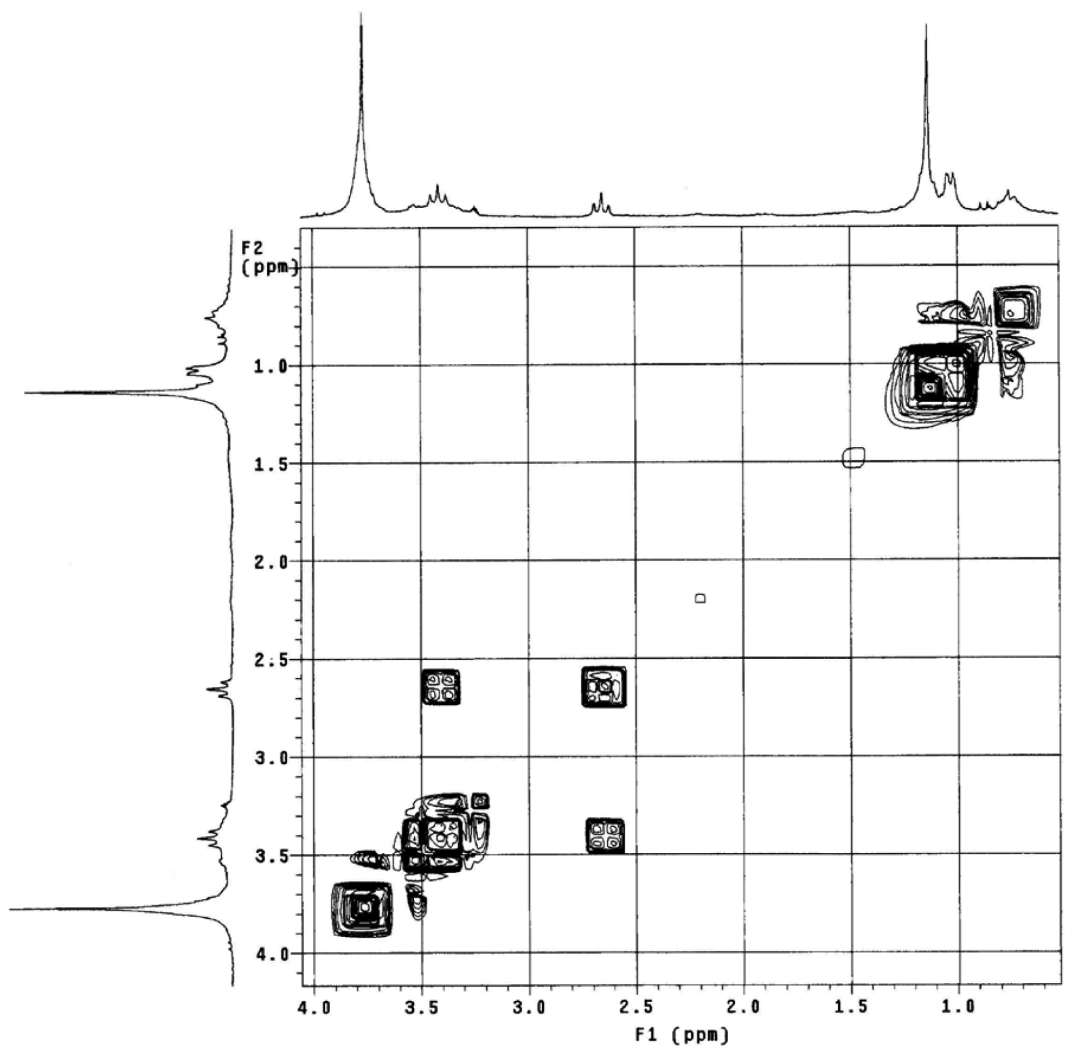

Figure 10S. Expansion of the ${ }^{1} \mathrm{H} x^{1} \mathrm{H}$-COSY NMR spectrum of $4\left(\delta, \mathrm{CDCl}_{3}, 200 \mathrm{MHz}\right)$

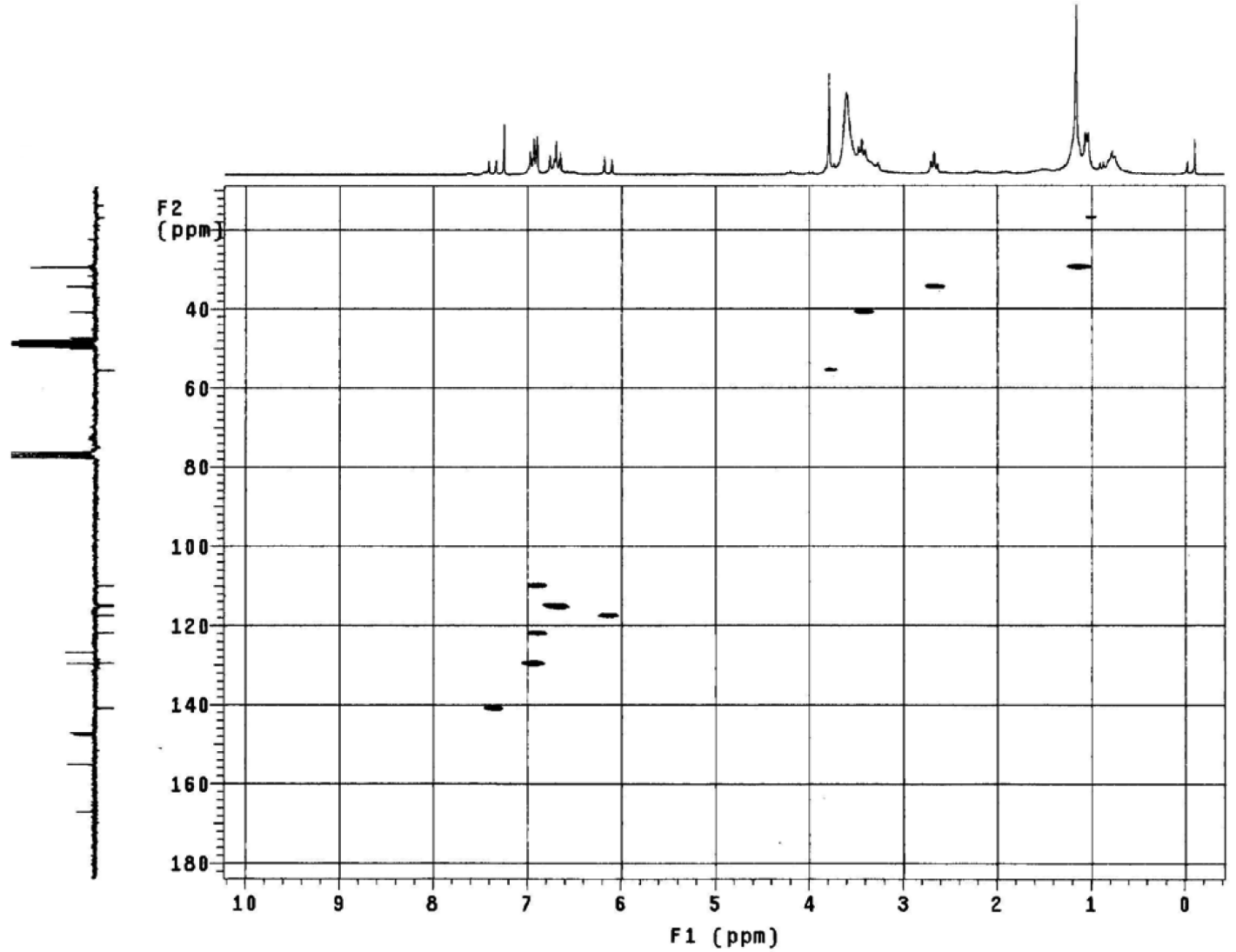

Figure 11S. ${ }^{1} \mathrm{H} \mathrm{x}{ }^{13} \mathrm{C}$-HETCOR NMR spectrum of $4\left(\delta, \mathrm{CDCl}_{3}, 200 \mathrm{MHz}\right)$ 


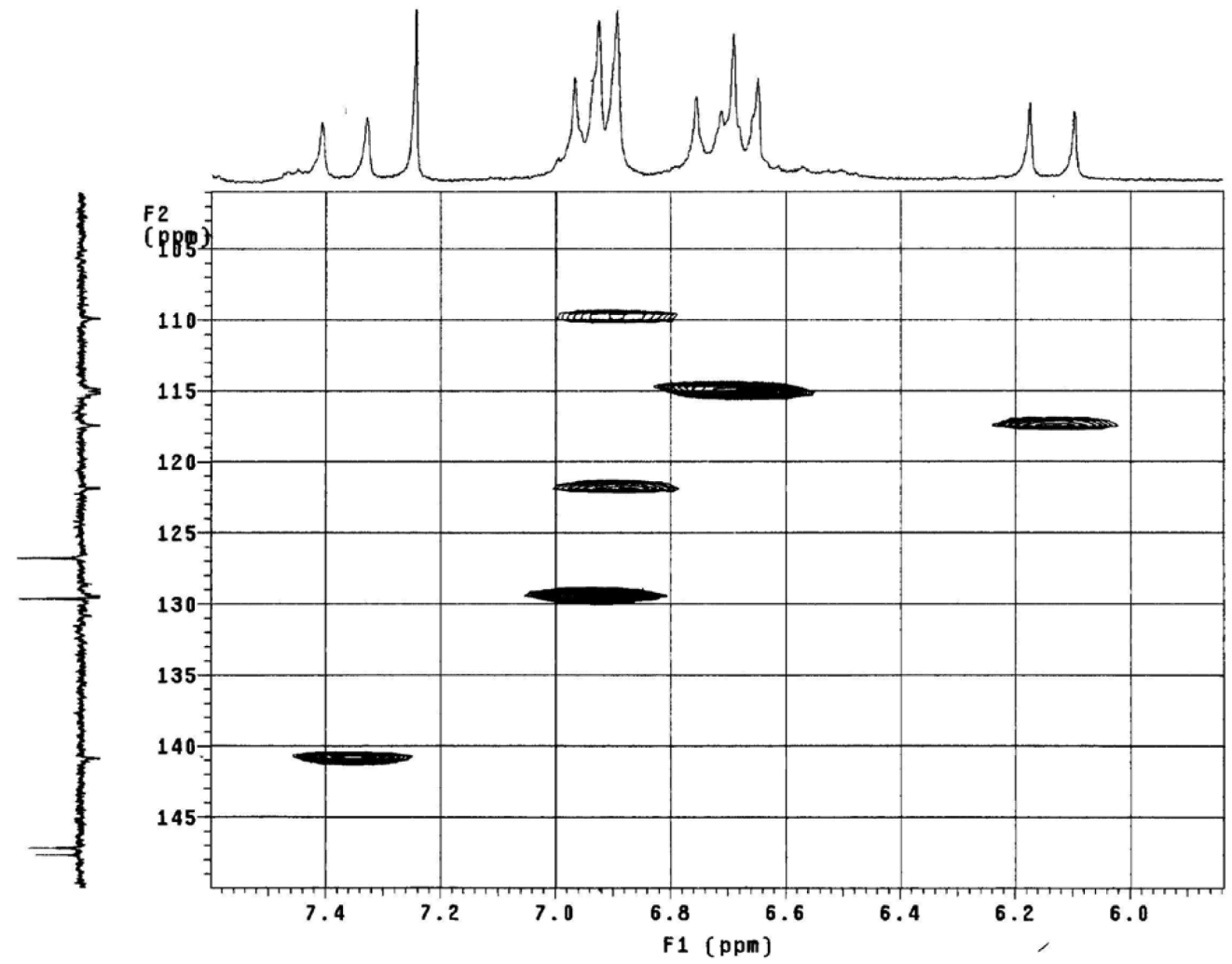

Figure 12S. Expansion of the ${ }^{l} \mathrm{H} x{ }^{13} \mathrm{C}$-HETCOR NMR spectrum of $4\left(\delta, \mathrm{CDCl}_{3}, 200 \mathrm{MHz}\right)$

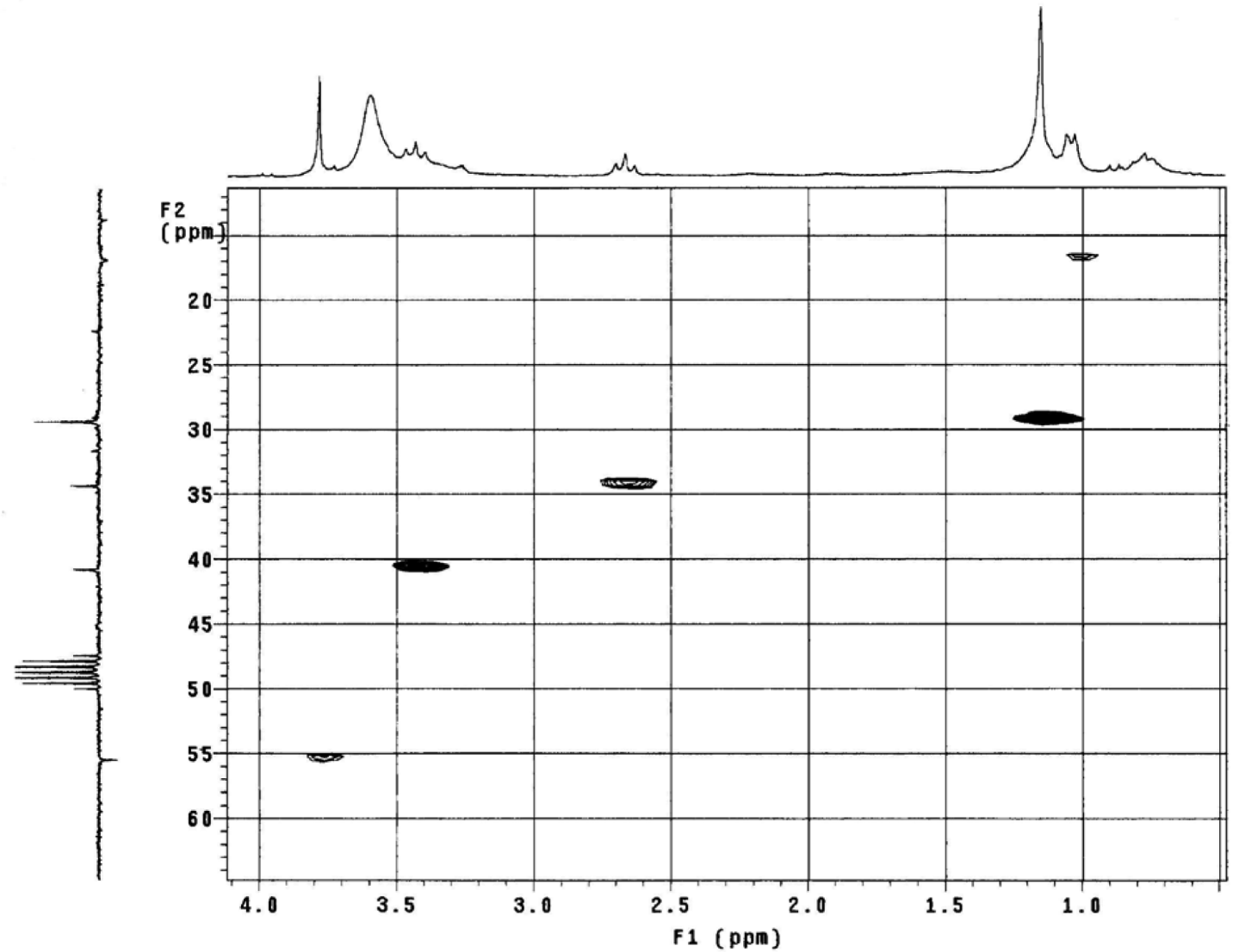

Figure 13S. Expansion of the ${ }^{1} \mathrm{H} x{ }^{13} \mathrm{C}$-HETCOR NMR spectrum of $4\left(\delta, \mathrm{CDCl}_{3}, 200 \mathrm{MHz}\right)$ 

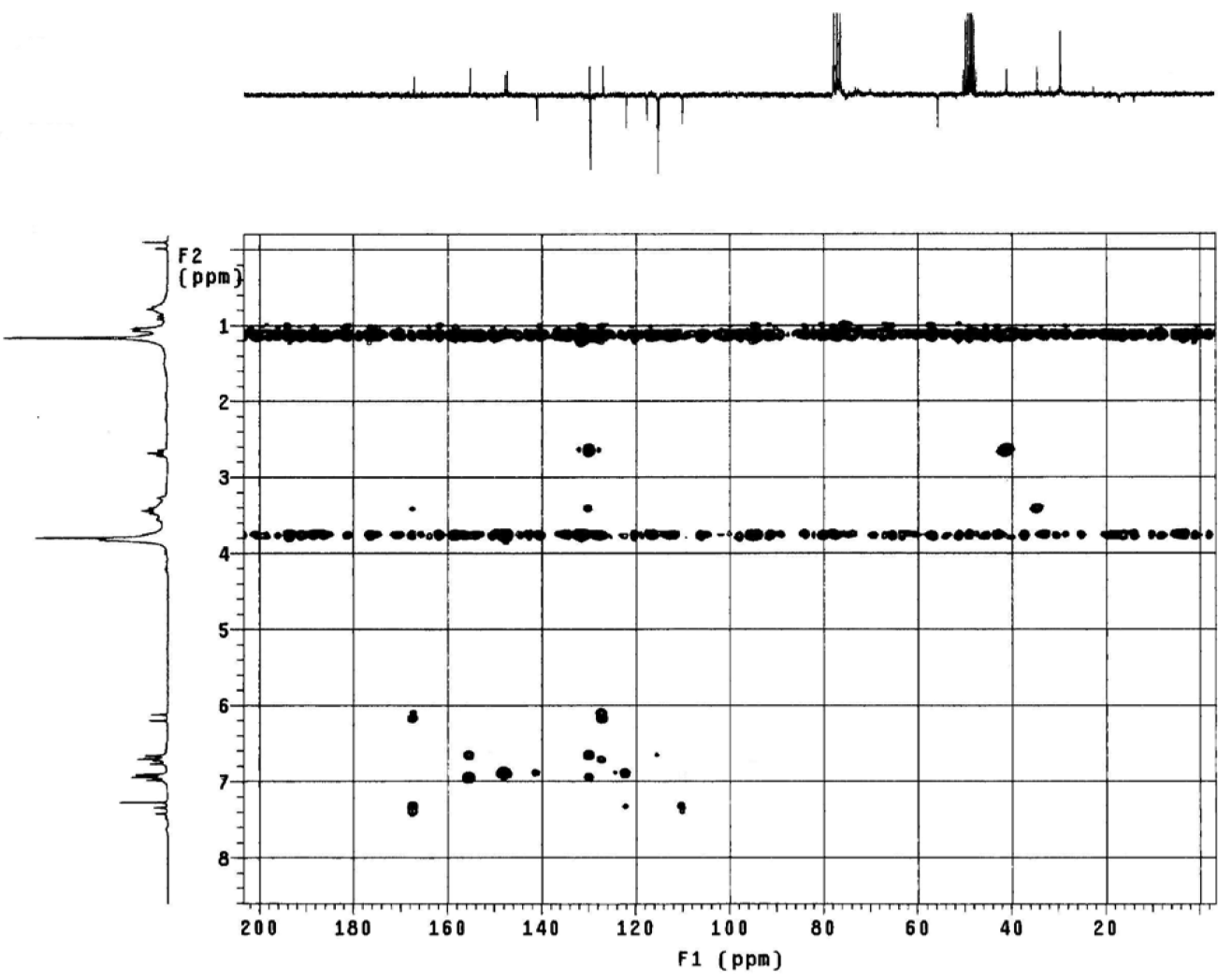

Figure 14S. ${ }^{1} \mathrm{H} x{ }^{13} \mathrm{C}$ - $\mathrm{HMBC} \mathrm{NMR}$ spectrum of $4\left(\delta, \mathrm{CDCl}_{3}, 200 \mathrm{MHz}\right)$

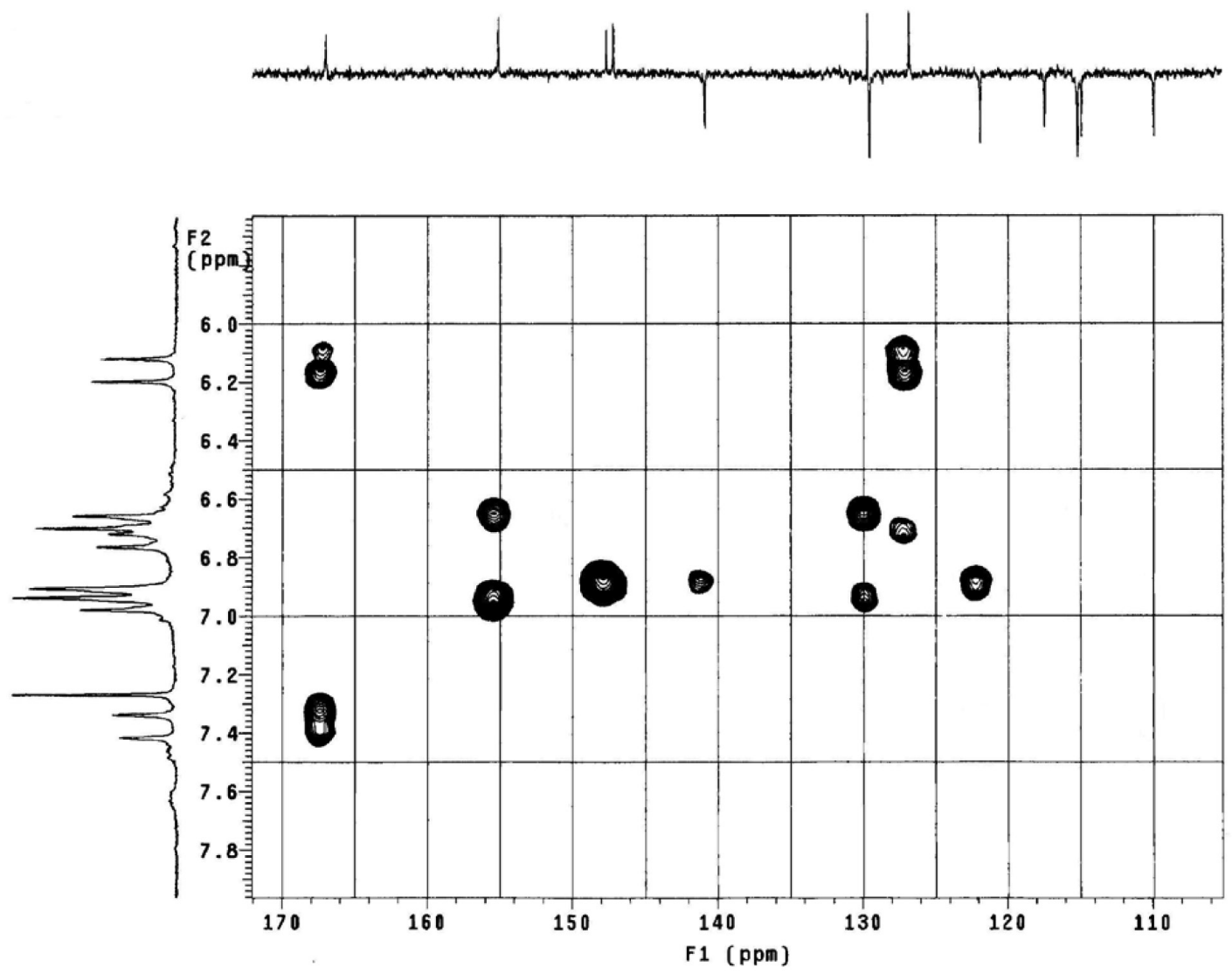

Figure 15S. Expansion of the ${ }^{1} \mathrm{H}{ }^{13} \mathrm{C}-\mathrm{HMBC} \mathrm{NMR}$ spectrum of $4\left(\delta, \mathrm{CDCl}_{3}, 200 \mathrm{MHz}\right)$ 

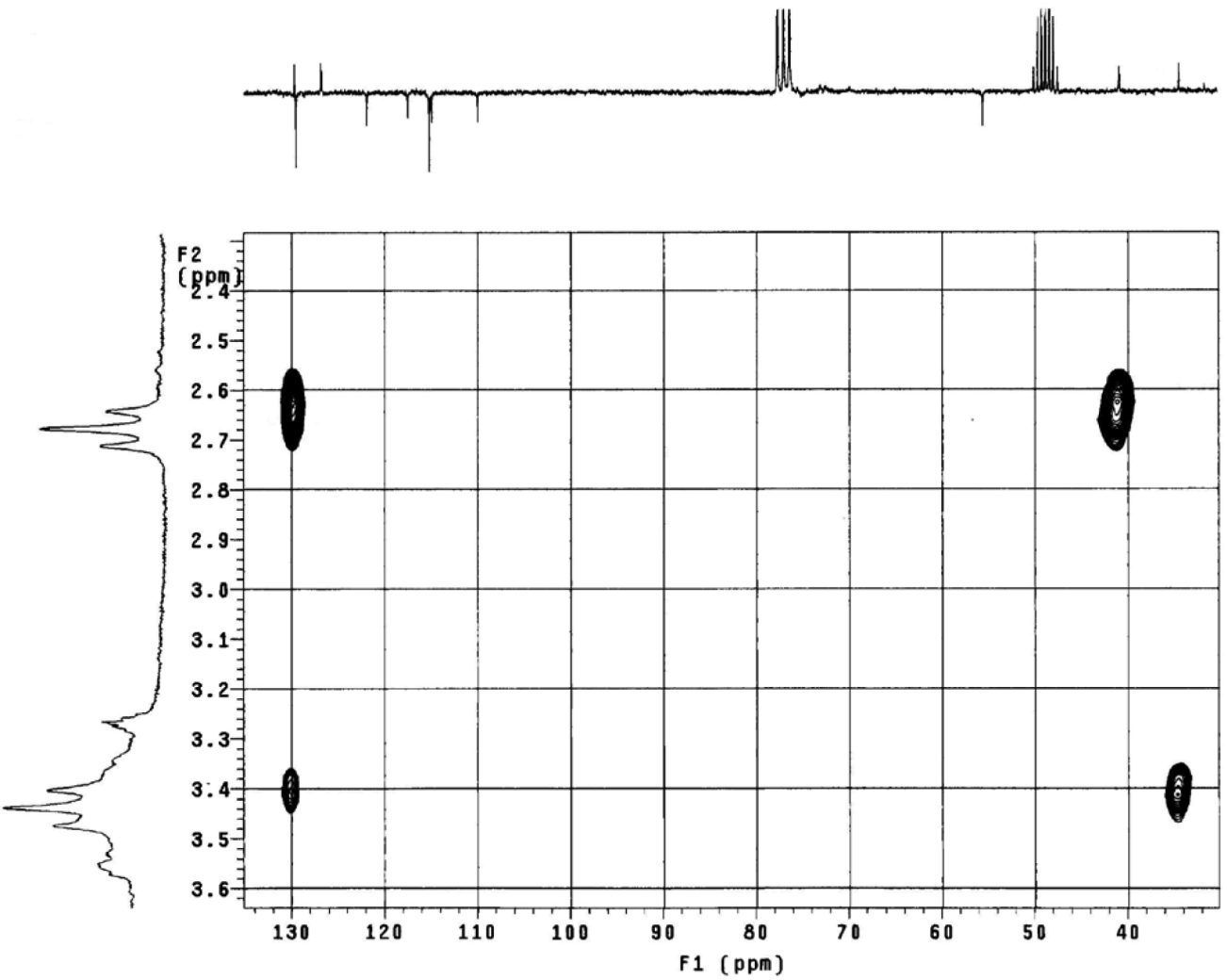

Figure 16S. Expansion of the ${ }^{1} \mathrm{H} x^{13} \mathrm{C}-\mathrm{HMBC} N \mathrm{NR}$ spectrum of $4\left(\delta, \mathrm{CDCl}_{3}, 200 \mathrm{MHz}\right)$

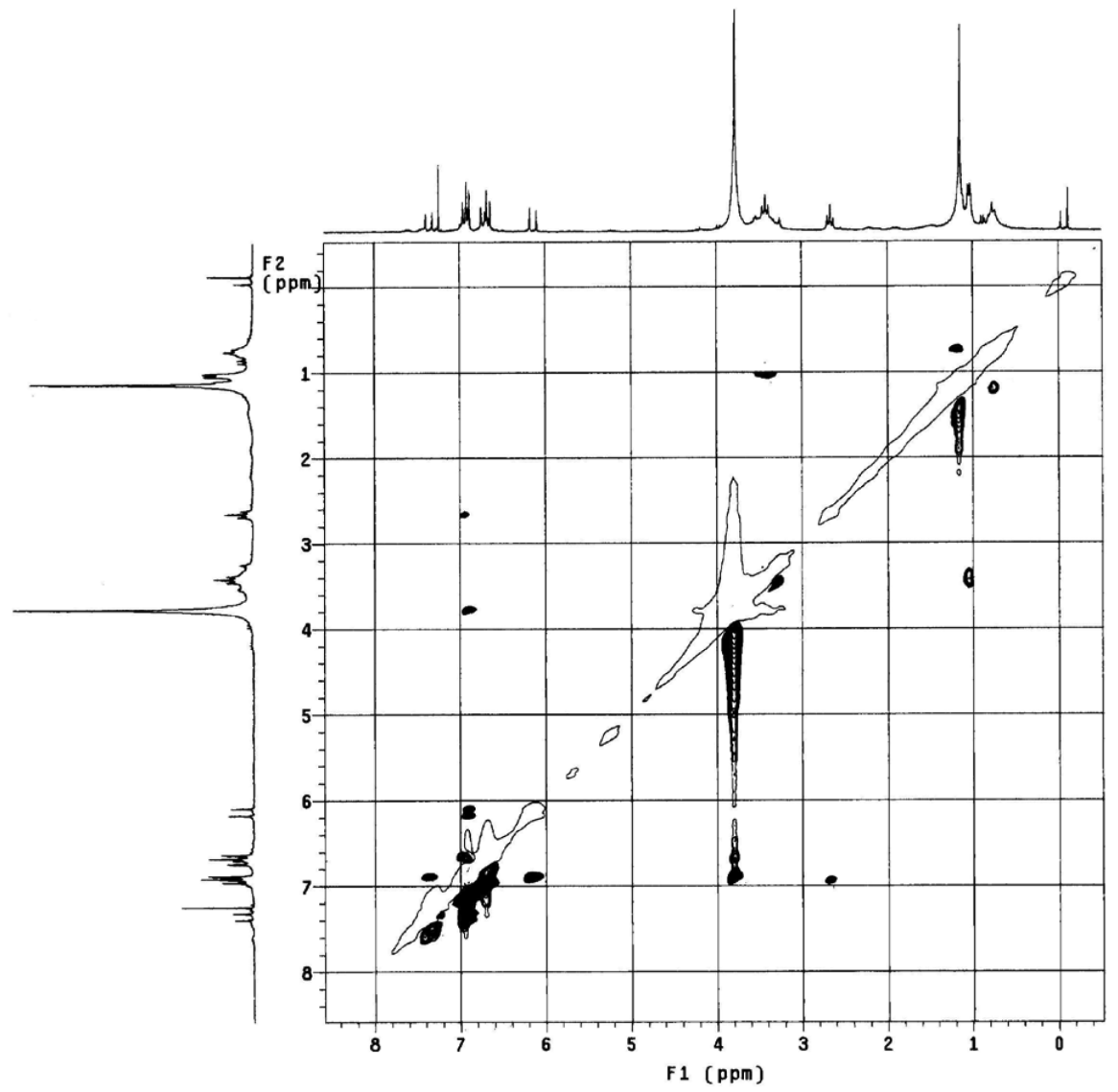

Figure 17S. ${ }^{1} \mathrm{H} x^{l} \mathrm{H}$-NOESY NMR spectrum of $4\left(\delta, \mathrm{CDCl}_{3}, 200 \mathrm{MHz}\right)$ 


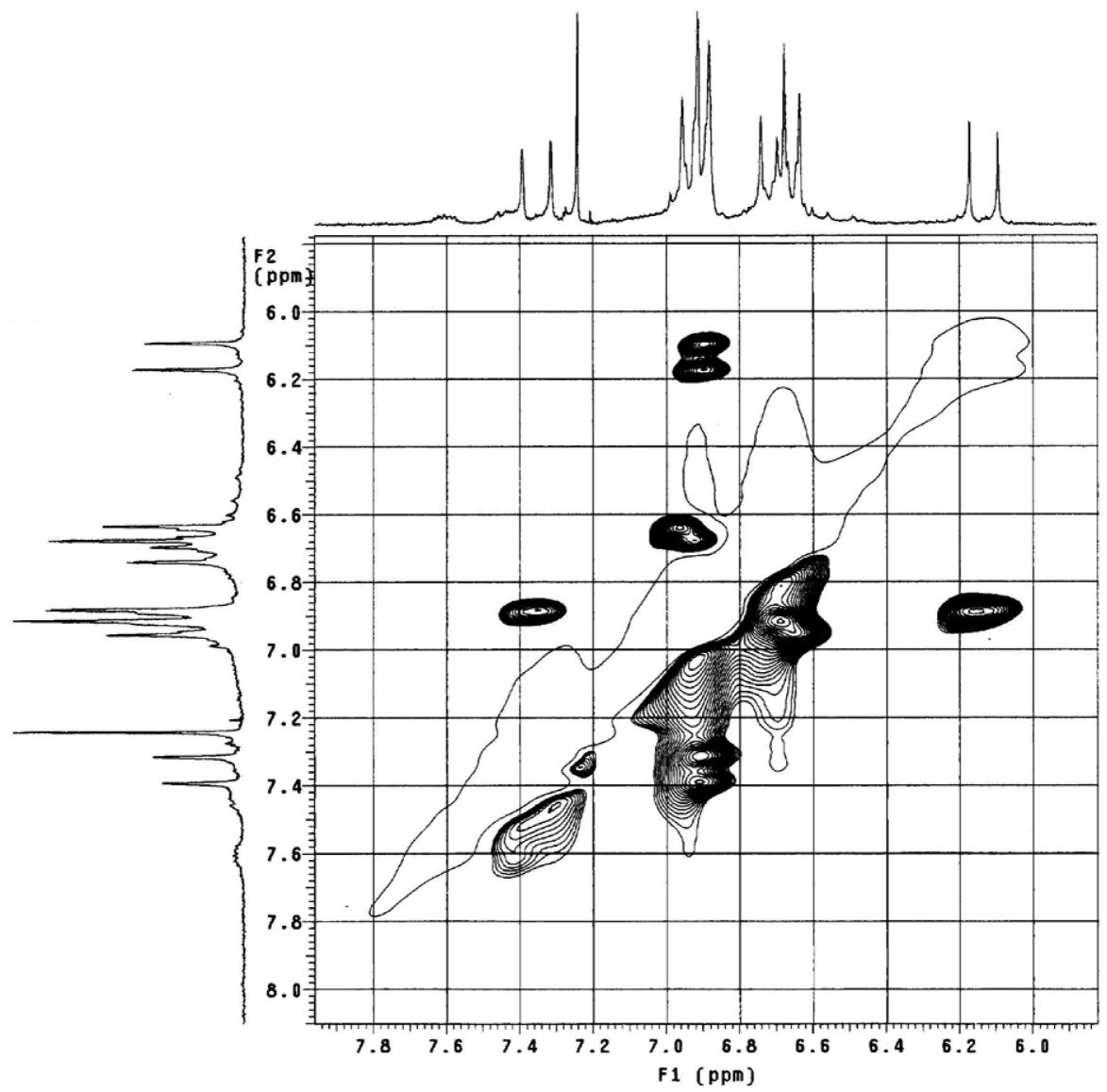

Figure 18S. Expansion of the ${ }^{l} \mathrm{H} x^{l} \mathrm{H}-\mathrm{NOESY} \mathrm{NMR}$ spectrum of $4\left(\delta, \mathrm{CDCl}_{3^{\prime}}, 200 \mathrm{MHz}\right)$ 